www.jmscr.igmpublication.org

Impact Factor 5.244

Index Copernicus Value: 83.27

ISSN (e)-2347-176x ISSN (p) 2455-0450

crossref DOI: _https://dx.doi.org/10.18535/jmscr/v4i11.48

Journal Of Medical Science And Clinical Research

\title{
Non Pathological Increase of Serum Liver Enzymes during Puerperium
}

\author{
Authors \\ Dr P.Guru Sankari ${ }^{1}$, Dr K. Lavanya Kumari², Dr S.Sethupathy ${ }^{3}$ \\ ${ }^{* 1}$ Junior Resident, Department of Obstetrics \& Gynecology, Rajah Muthiah Medical College and Hospital, \\ Annamalai University, Chidambaram \\ ${ }^{2}$ Head of the Department, Department of Obstetrics \& Gynecology, Rajah Muthiah Medical College and \\ Hospital, Annamalai University, Chidambaram \\ ${ }^{3}$ Head of the Department, Department of Biochemistry, Rajah Muthiah Medical College and Hospital, \\ Annamalai University, Chidambaram
}

\begin{abstract}
Background: Measurement of liver function in pregnancy and puerperium is very important as the diagnosis and management of a number of potential complications such as pre-eclampsia, syndrome of haemolysis, HELLP syndrome (elevated liver enzymes, and low platelets), acute fatty liver of pregnancy and obstetric intrahepatic cholestasis depends on proper estimation of liver function tests (LFTs). All these conditions may occur for the first time in pureperium or deteriorate in the puerperium. This study was carried out at Rajah Muthiah Medical College, Chidambaram to assess the liver function tests in the puerperium in uncomplicated pregnancies.

Materials and Methods: Ninety (90) antenatal women with gestational age between 37 \& 40 weeks who delivered without any antenatal complication were selected in this prospective study. Information was collected after detailed history taking and complete physical examination. Blood samples were collected for liver function tests just before delivery, 48 hours after delivery (day 2), on day 5 and on day 10. Statistical analysis of the results of LFT values was done using ANOVA test.

Results: There was 10\% increase in serum AST levels after delivery on Day 2 and another 9\% on Day 5 in comparison to antenatal period and it dropped back to pre-delivery levels on day 10. There was 9\% increase in serum ALT levels after delivery on Day 2 and $11 \%$ on Day 5 in comparison to antenatal period and on $10^{\text {th }}$ day it dropped back to pre-delivery levels. There was $14 \%$ increase in serum ALP levels after delivery on day 2 and $16 \%$ on day 5 in comparison to antenatal period and on 10th day there was only 10\% drop from day 5 levels and did not reach the pre-delivery levels. Other parameters like total protein, serum albumin and globulin, total bilirubin and direct bilirubin were unaffected.

Conclusion: Only the transaminase levels (AST and ALT) and alkaline phosphatase levels were significantly higher after delivery on day 2, 5 and declined to pre-delivery levels by post-operative day 10 except for alkaline phosphatase. These findings should be kept in mind while interpreting the liver function test results in the immediate post-partum period. If the enzyme levels remain raised even after 10 days into post-partum period, it may be a warning sign of underlying liver dysfunction.

Keywords: Liver Function Tests (LFT), Non pathological Puerperium.
\end{abstract}




\section{INTRODUCTION}

Pregnancy is a special physiological phenomenon with a range of physiological changes that influence almost all body organs including the liver. Moreover, many obstetric conditions also can affect the liver function and result in several complications $^{2}$. Measurement of liver function in pregnancy and the puerperium is very important as the diagnosis and management of a number of potential complications such as pre-eclampsia, HELLP syndrome (syndrome of hemolysis, elevated liver enzymes, and low platelets), acute fatty liver of pregnancy and obstetric intrahepatic cholestasis this depends on proper estimation of liver function tests (LFTs). All these conditions may occur for the first time or deteriorate in the puerperium. Literature regarding changes in LFTs after delivery is very limited. Few earlier studies ${ }^{3}$ have shown some changes in LFT during pregnancy. The laboratory test results should be carefully interpreted and the knowledge of the normal changes associated with pregnancy and delivery is prudent to avoid clinical misjudgement, Hence, this study was aimed at studying the influence of uncomplicated delivery and puerperium on liver function tests by comparing with pre-delivery levels and post- delivery levels.

\section{METHODOLOGY}

Ninety antenatal women with gestational age between $37 \& 40$ weeks who was admitted in the Department of Obstetrics and Gynaecology, Rajah Muthiah Medical College and Hospital, Annamalai University, Chidambaram were selected for this prospective observational study approved by Institutional Human ethics committee (M18/RMMC/2015).

INCLUSION CRITERIA: Antenatal cases with gestational age between $37 \& 40$ wks, without any antenatal complications and delivered in the hospital were selected for the study. All these study subjects were incidentally delivered by lower segment caesarian section (LSCS). Cases were selected irrespective of age, parity and socioeconomic status.

EXCLUSION CRITERIA: Women with pregnancy associated complications like diabetes mellitus, heart disease, fetal anomalies, liver disease and on medications which can alter liver function. Blood samples were collected from ante cubital vein by venepuncture from women in early labour or at the onset of labour pains or on the day of elective lower segment caesarian section after fasting of about 6 hours. Postpartum samples were taken from each women on 48 hours after delivery (day 2), post-operative day 5 and on postoperative day 10. All assays were performed with an automated multi-channel analyzer using standard methods for estimation. Statistical analysis was done using SPSS version 20.0. ANOVA test was used.For all the statistical tests of significance, $\mathrm{p}$ value of $<0.05$ was considered significant.

\section{RESULTS}

About $64 \%$ of the study subjects were in the age group of 21 to 25 years. About $44.5 \%$ of the study subjects were primi gravida and $55 \%$ of the study subjects were multigravida. Among multigravida, $70 \%$ had delivered previously through LSCS while the remaining $30 \%$ had previous normal delivery. About $69 \%$ of the study subjects delivered during 37- 40 weeks and $31 \%$ of the study subjects delivered at 40 weeks. The mean serum AST and ALT levels raised steadily after delivery on day 2 and day 5 in comparison to antenatal period and then it dropped back to predelivery levels on postnatal Day 10 (p value < 0.05). The mean serum ALP levels also raised steadily after delivery on day 2 and day 5 in comparison to antenatal period and though it declined by tenth day, it did not reach down to pre-delivery levels ( $\mathrm{p}$ value $<0.05$ ). The changes in mean levels of other biochemical parameters like total bilirubin, direct bilirubin, total protein, serum albumin and serum globulin after delivery was not statistically significant. 
Table 1Baseline Charecteristics of The Study Subjects

\begin{tabular}{|l|l|}
\hline Parameter & $\mathrm{n}=90 ;$ Mean \pm SD \\
\hline Maternal age (Years) & $24.78 \pm 2.43$ \\
\hline Gestational age (weeks) & $38.7 \pm 1.1$ \\
\hline Hb (g/dl) & $10.21 \pm 0.71$ \\
\hline RBS (mg/dl) & $100.10 \pm 12.31$ \\
\hline Wt of the mother (Kg) & $61.31 \pm 7.41$ \\
\hline Birth wt of the Baby (gms) & $2906 \pm 311$ \\
\hline
\end{tabular}

Table 2 Distribution of the study population according to liver function tests at various time intervals (predelivery, post partum day 2,5 , and 10$)(n=90)$

\begin{tabular}{|l|c|c|c|c|c|}
\hline \multirow{2}{*}{ Liver function test } & \multicolumn{3}{|c|}{ Mean levels \pm Std. Deviation } & \multirow{2}{*}{ Postnatal } \\
\cline { 2 - 5 } & $\begin{array}{c}\text { Pre-delivery } \\
\text { level }\end{array}$ & $\begin{array}{c}\text { Postnatal } \\
\text { Day 2 }\end{array}$ & $\begin{array}{c}\text { Postnatal } \\
\text { Day } 5\end{array}$ & value \\
\hline Total bilirubin $(\mathrm{mg} / \mathrm{dl})$ & $0.76 \pm 0.07$ & $0.76 \pm 0.08$ & $0.78 \pm 0.12$ & $0.75 \pm 0.11$ & 0.151 \\
\hline Direct bilirubin $(\mathrm{mg} / \mathrm{dl})$ & $0.15 \pm 0.05$ & $0.16 \pm 0.12$ & $0.17 \pm 0.14$ & $0.16 \pm 0.10$ & 0.787 \\
\hline AST $(\mathrm{IU} / \mathrm{L})$ & $30.66 \pm 6.64$ & $33.31 \pm 6.36$ & $35.04 \pm 6.09$ & $31.18 \pm 6.37$ & $<0.001$ \\
\hline ALT $(\mathrm{IU} / \mathrm{L})$ & $33.07 \pm 7.41$ & $35.70 \pm 6.9$ & $37.66 \pm 7.03$ & $34.06 \pm 7.12$ & $<0.001$ \\
\hline ALP $(\mathrm{IU} / \mathrm{L})$ & $153.02 \pm 30.9$ & $173.59 \pm 33.0$ & $177.92 \pm 30.45$ & $159.34 \pm 30.02$ & $<0.001$ \\
\hline Total Protein $(\mathrm{g} / \mathrm{dl})$ & $5.98 \pm 0.67$ & $5.96 \pm 0.62$ & $5.94 \pm 0.62$ & $5.84 \pm 0.65$ & 0.481 \\
\hline Serum albumin $(\mathrm{g} / \mathrm{dl})$ & $3.21 \pm 0.29$ & $3.20 \pm 0.23$ & $3.24 \pm 0.29$ & $3.13 \pm 0.28$ & 0.059 \\
\hline Serum globulin $(\mathrm{g} / \mathrm{dl})$ & $3.00 \pm 0.48$ & $3.02 \pm 0.47$ & $3.03 \pm 0.44$ & $2.96 \pm 0.42$ & 0.729 \\
\hline
\end{tabular}
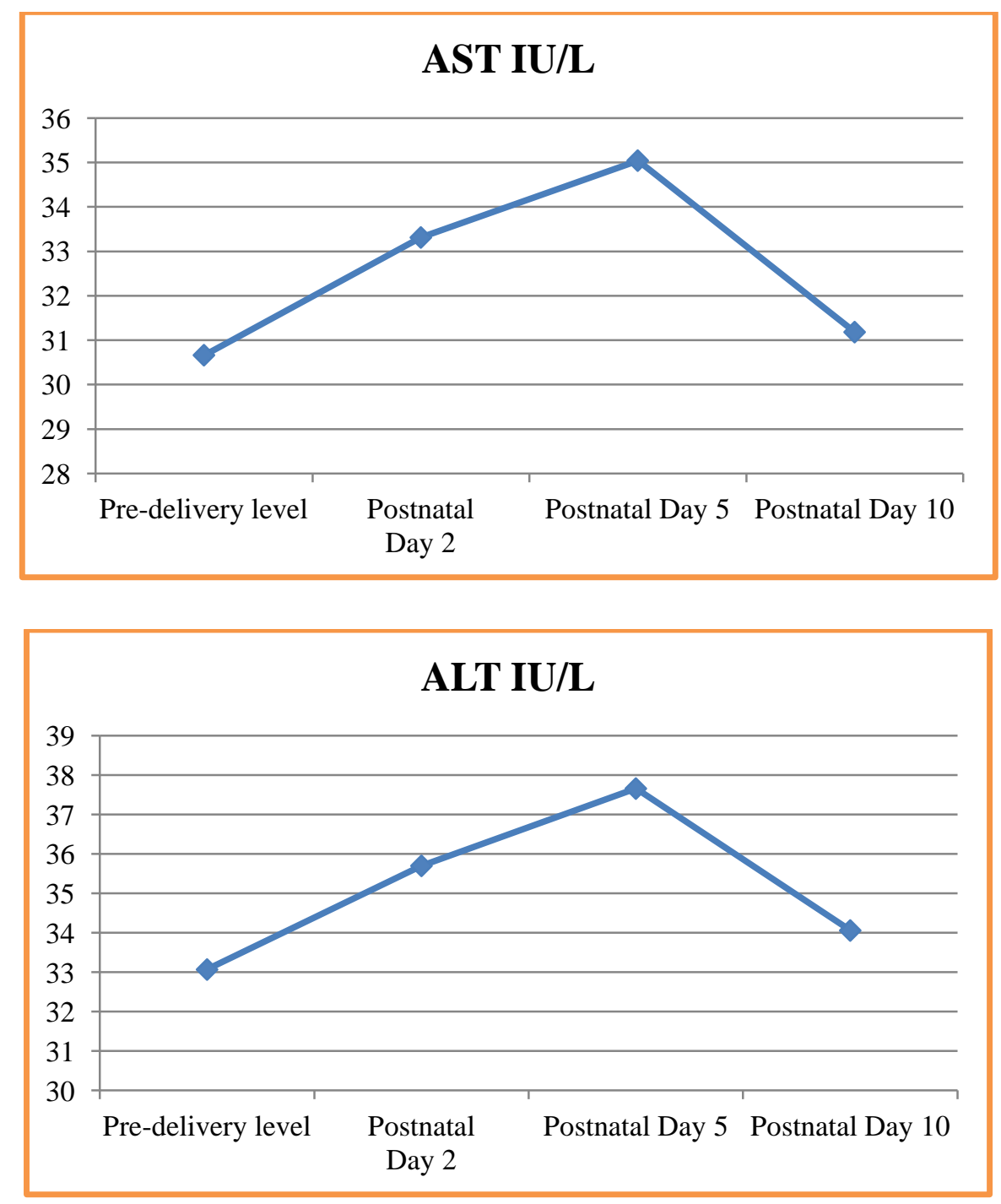


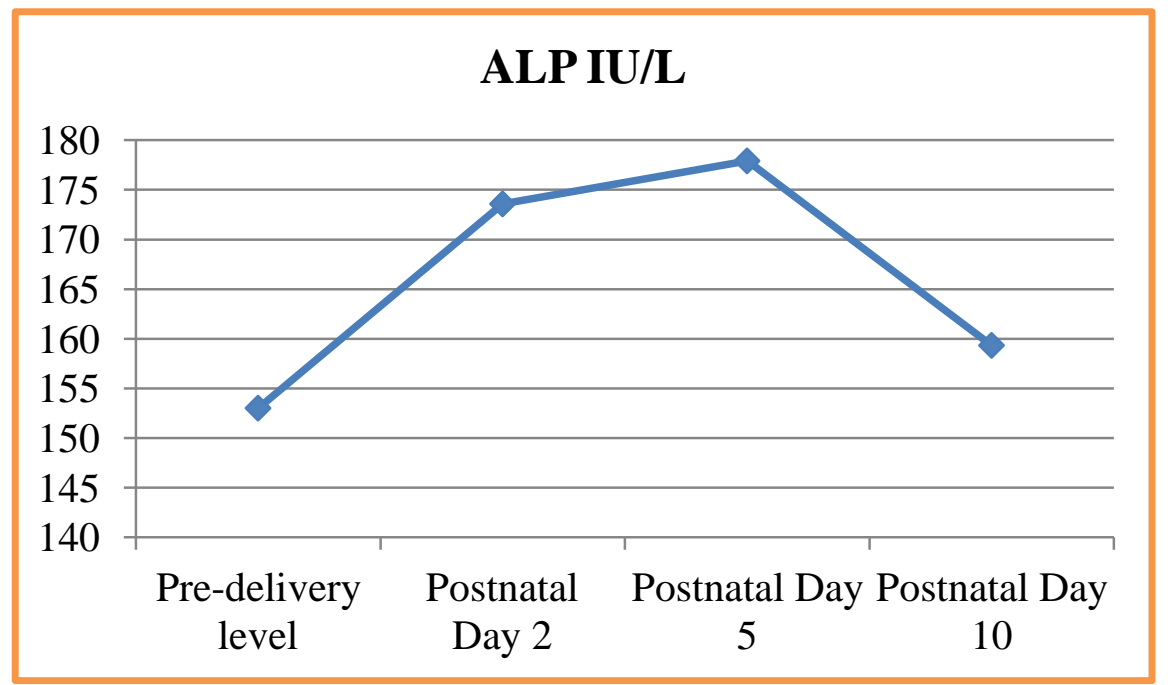

\section{DISCUSSION}

Many obstetric conditions can affect the liver functions and result in several complications ${ }^{2}$. There was significant changes in serum AST, ALT and ALP levels which raised steadily after delivery on day 2 and day 5 except ALP, others dropped back to pre-delivery levels on postnatal Day 10 ( $\mathrm{p}<0.05)$. Hence, this study findings depict that the levels of liver enzymes such as serum AST, ALT and ALP levels rise significantly in the immediate postpartum period ( $10-20 \%)$ and returns to normal pre-delivery levels by day 10 except for ALP levels (15-20\%) which may need even longer time period to fall back to pre-delivery levels.

The bio-synthetic function of liver remains unaffected as evident by insignificant changes in levels of total protein, serum albumin. The excretory activity of liver remains unaffected as revealed but normal serum bilirubin. The small significant changes in serum AST, ALT might be due to 1.mild liver cell damage, 2.Cholestasis and 3. Hemodynamic changes influencing blood levels. Anaesthesia and caesarean section itself can have an impact on the $\mathrm{LFT}^{4}$. Anaesthesia causes a moderate reduction in hepatic arterial blood flow and hepatic oxygen uptake and either the initial hypo-perfusion during anaesthesia or reperfusion injury, or both, may contribute to postoperative liver dysfunction ${ }^{5}$. The volatile anaesthetics halothane and enflurane if used will reduce hepatic arterial blood flow as a result of systemic vasodilatation and also halothane is known to cause hepatitis ${ }^{6,7}$ None of our study cases received these inhalant anaesthetic drugs. Lower segment caesarean section itself leads to a reduction in hepatic arterial blood flow in part because of the traction on the abdominal viscera which may cause reflex systemic hypotension as a result of dilatation of capacitance vessels. Moreover, the greater the degree of haemorrhage with surgery, the greater the fall in hepatic blood flow and chance of ischemic injury to the liver. In our study, bupivacaine was used which does not cause liver damage. ${ }^{7}$ In intra hepatic cholestasis, there will be much elevation of serum alkaline phosphatase and bilirubin levels may also be elevated. The mild elevation of serum ALP suggests that it could have originated from placenta. ${ }^{9,11}$ Before delivery, hemodilution and after delivery, hemoconcentration might influence the serum liver enzyme levels ${ }^{9}$. Hence, the mild elevations in serum hepatic enzymes could be due to hemodynamic changes and could not be pathological.

\section{CONCLUSION}

Based on the study findings, it can be concluded that among various liver function tests, only the transaminase levels (AST and ALT) and alkaline phosphatase levels rise significantly immediately after delivery and this rise is short-lived as it returns back to pre-delivery levels by day 10 of the post-operative day except for alkaline 
phosphatase which requires a little longer time to fall back to pre-delivery levels. This should be kept in mind while interpreting the liver function test results in the immediate post-partum period till $10^{\text {th }}$ post-operative day. If the enzyme levels remain raised even after 10 days of post-partum period, it should be interpreted with caution as this may be a warning sign of underlying liver dysfunction. Further research is needed to explain the basis of such changes in puerperium and the role of various factors influencing their levels.

\section{CONFLICT OF INTEREST: Nil.}

No external funding.

\section{REFERENCES}

1. Friedman LS, Maddrey WC; Surgery in the patient with liver disease. Med Clin North Am.1987;71(3):453.

2. Corton MM, Leveno $\mathrm{K}$, Bloom $\mathrm{S}$, Hoffman B. Williams Obstetrics 24/E (EBOOK). McGraw Hill Professional; 2014 May 6.

3. David, A. L., Kotecha, M. and Girling, J. C. (2000), Factors influencing postnatal liver function tests. BJOG: An International Journal of Obstetrics \& Gynaecology, 107: 1421-1426.

4. Strunin L. Anesthetic management of patients with liver disease. In: MillwardSadler GH, Wright R, Arthur MJP, eds. Wright's Liver and Biliary Disease. London: Saunders 1992; 1381-1393.

5. Cowan RE, Jackson BT, Grainger SL, Thompson RPH. Effects of anesthetic agents and abdominal surgery on liver blood flow. HEPATOLOGY 1991; 14:1161-1166.

6. Batchelder BM, Cooperman LH. Effects of anesthetics on splanchnic circulation and metabolism. Surg Clin North Am 1975;55:787-794.

7. Ngai SH. Effects of anesthetics on various organs. N Engl J Med 1980;302:564-566
8. Ropponen A, Sund R, Riikonen S, Ylikorkala O, Aittomäki K. Intrahepatic cholestasis of pregnancy as an indicator of liver and biliary diease: A populationbased study. Hepatology. 2006;43:723-8.

9. Lata I. Hepatobiliary diseases during pregnancy and their management: An update. International journal of critical illness and injury science. 2013 Jul;3(3):175.

10. Adeniyi FA, Olatunbosun DA. Origins and significance of the increased plasma alkaline phophatase during normal pregnancy and preeclampsia. Br J Obstet Gynaecol.1984;91(9):857-862

11. Valenzuela GJ, Munson LA, Tarbaux NM.et al. Time-dépendent changes in bone, placental, intestinal, and hepatic alkaline phosphatase activities in serum during human pregnancy. Clin Chem. 1987; 33(10):1801-1806. 